successful use of this tissue processor in preparing pancreases is important because this device is far less expensive than the tissue chopper used by other investigators [6]. Our experimental and clinical data indicates that there are no compromises in the results obtained by its utilization.

Sincerely,

Debra A. Gordon,

Gerald H. MacKenzie, and

Luis $\mathrm{H}$. Toledo-Pereyra

\section{References}

1. Ballinger WF, Lacy PF (1972) Transplantation of intact pancreatic islets in rats. Surgery $72: 175-186$

2. Lacy PE, Kistianovsky M (1967) A method for the isolation of intact islets of Langerhans from the rat pancreas. Diabetes 16: 35

3. Lindail $A W$, Steffes MW, Sorenson R (1969) Immunoassayable insulin content of subcellular fractions of rat islets. Endocrinology 85: 218-223

4. Mirkovitch V, Campiche $M$ (1976) Successful intrasplenic autotransplantation of pancreatic tissue in totally pancreatectomized dogs. Transplantation 21: $265-269$

5. Kretschmer GJ; Sutherland DER, Matas AJ, Cain TL, Najarian IS (1977) Autotransplantation of pancreatic islets without separation of exocrine and endocrine tissue in totally pancreatectomized dogs. Surgery 82: 74-81

6. Matas AJ, Sutherland DER, Steffes MW, Najarian JS (1976) Short-term culture of adult pancreatic fragments for purification and transplantation of islets of Langerhans. Surgery 80 : 183-191

Luis H. Toledo-Pereyra, M. D., Ph. D.

Mount Carmel Mercy Hospital

Department of Surgery

Section of Transplantation and

Surgical Research

Detroit, MI 48235

USA

\title{
Rapid Glycosylation of Haemoglobin
}

Sir,

We would like to comment further on the very thorough work on rapid glycosylation of haemoglobin as determined by column chromatography reported by Dr. Svedsen and colleagues in the August issue of Diabetologia. Our studies on short term glycosylation in vitro and in vivo fully support those of Dr. Svedsen in demonstrating a rapid rise in levels as detected by Quik-sep column chromatography though not by the Fluckiger technique.

We would like to add some further details. Firstly, rapid glycosylation continues in vitro at $23^{\circ} \mathrm{C}$ (room temperature) in EDTA blood samples with a high glucose concentration; thus at a blood glucose concentration of $25 \mathrm{mmol} / 1$ the $\mathrm{HbA}_{1}$ level measured by column chromatography increased from $7-9 \%$ in $6 \mathrm{~h}$. Secondly, rapid glycosylation was reversed by incubation of red cells washed in saline at $23^{\circ} \mathrm{C}$ for $8-12 \mathrm{~h}$, and the $\% \mathrm{HbA}_{1}$ level then remained stable for the next $24 \mathrm{~h}$. This is simpler than $37^{\circ} \mathrm{C}$ incubation, and avoids another possible source of error. This is that at $37^{\circ} \mathrm{C}$, incubation of washed red cells for more than $12 \mathrm{~h}$ results in an unpredictable increase in $\% \mathrm{HbA}_{1}$ levels measured by column chromatography, which is associated with denaturation of haemo- globin shown by change in absorption spectrum and ultimately visible change in colout of the samples.

This means that it is unlikely to be safe to incubate all blood samples overnight at $37^{\circ} \mathrm{C}$ before measurement of glycosylated haemoglobin. In routine laboratories where overnight preparation of samples (approximately $16-18 \mathrm{~h}$ ) is more convenient than $7 \mathrm{~h}$ incubation, it might be best to keep thoroughly washed red cells al room temperature for $16-24$ h before assay. This requires a lowering of the normal range by approximately $1 \%$ glycosylatec haemoglobin.

Yours sincerely, R. Paisey, C. Pennock, Caroline Owens, M. Hartog, D. White

R. Paisey

Department of Medicine

Southmead Hospital

Southmead Road

Bristol BS $105 \mathrm{NB}$

England 